\title{
The role of insurance in social protection
}

\section{Daniel Titelman}

Specialist in Monetary and Financial Policies, Special Studies Unit, ECLAC

dtitelman@eclac.cl

Andras Uthoff

Coordinator,

Special Studies Unit,

ECLAC

authoff@eclac.cl
Social protection systems have to cope with large discrepancies between the financing needed to cover demand and the resources actually available. For this reason, it is necessary for any reform proposal to include elements of cost restraint as well as measures to increase the population coverage of systems. Efficiency and solidarity must improve together if progress is to be made towards universality of benefits. Any reform strategy needs to consider not only the financial constraints imposed by the macroeconomy, but also the heavy drain on financial resources and the effects on the fiscal accounts that may result from whatever scheme is chosen owing to the amount and volume of benefits, the limited scope for funding them out of contributions, and the need for redistributive financing. This article looks at various approaches to social security finance reform, involving new and different public-private mixes. 


\section{I}

\section{Introduction}

Demand for health services and pensions (and for other social protection benefits) is now growing considerably faster than actual gross domestic product (GDP) or any forecast for GDP, however optimistic. This has led to mounting tension between the financial requirements of social security and the capacity of countries to provide the resources demanded.

This being so, reform of social protection systems has come to be a core part of the political agenda in most countries. In the region, the need for change results simultaneously from two considerations. First, there are the failings and difficulties that have beset social protection (social insurance and the public sector) in the past and the new challenges raised by demographic and epidemiological trends and technological developments. Second, these internal challenges are being compounded by globalization, which the countries of the region are now undergoing and which has affected the nature of the protection system and its ability to respond to the external shocks faced by our economies. In particular, the financial volatility of the 1990s has had major repercussions for the countries' business cycles, increasing social risk and the need for social protection mechanisms (Rodrik, 2001; ECLAC, 2001a). Companies have adapted to greater economic instability by adjusting their workforces, and this has resulted in growing insecurity of employment at the national level, weakening the contribution base of social protection systems. ${ }^{1}$

$\square$ A version of this paper was presented at the "Macroeconomic policy and social vulnerability" seminar held in Santiago, Chile, on 26 and 27 November 2002 as part of a project jointly financed by the United Nations Department of Economic and Social Affairs and the Governments of France and Germany. The authors are grateful for the comments of seminar participants, particularly those made by Ricardo Ffrench-Davis, José Pablo Arellano and Oscar Altimir on a preliminary text.

${ }^{1}$ Specifically, this paper will consider how risks relating to health, old age, disability and death are covered. It does not deal with unemployment and social exclusion risks, except as they affect people's ability to participate in contributory social protection systems. The average unemployment rate in Latin America rose by more than four percentage points in the 1990s; according to ECLAC estimates, seven of every 10 jobs were generated in the informal sector in that decade.
From the outset, social protection systems have been regarded as social entitlements. Their objectives include combating poverty, discrimination and social risks (United Nations, 2002). Reforms intended to modernize these systems still have to meet three historic challenges: i) universalizing social security; ii) reducing marked inequities in service access and quality, and iii) improving the social return on the resources allocated to these activities by changing the way they are managed and assigned. Reforms need to be designed to strengthen social security systems so that the insurance structure can be adapted to the new needs and realities of society and the economy, particularly changes in labour markets.

In this article, it will be argued that the heterogeneity of labour markets and the volatility and uncertainty of the economic environment have increased social risk. Social security systems need to combine insurance and saving schemes with redistribution and solidarity. Since any progress towards universal coverage and guaranteed benefits means greater financial demands on the State, reforms need to succeed in reconciling social and fiscal responsibilities. One example of these demands is the growth of contingent liabilities generated in the public sector, requiring rules for financing them over time (Arenas de Mesa and Guzmán, 2003). If it is to support social policies, macroeconomic policy should not only be concerned with smoothing out business cycles but should also generate fiscal expenditure rules that include scope for countercyclical public spending compatible with the basis of this policy. The design of the public-private mix will have a significant influence on the efficiency and equity of the social security system, and thence on the demands made on the treasury. In the case of health systems, an inappropriate public-private mix leads to problems of risk selection and exclusion. In the case of pensions, while the need to replace defined-benefit systems with defined-contribution ones is recognized, the design of reform options has major implications for the costs that have to be met by the treasury during the transition and for the financing sources of solidarity pension schemes for those unable to contribute. 
This article will also look at the new context in which social security systems will have to operate, review the particular health and pension reforms carried out by countries in the region, and analyse the policy challenges arising from the reform process.

\section{II}

\section{Public-sector social spending}

The countries of the region have made a considerable commitment to social spending. As a percentage of GDP, spending rose from $10.4 \%$ in $1990-1991$ to $14.1 \%$ in 2000-2001, showing a modestly countercyclical tendency (table 1). A significant effort has also been made with health spending. The region spends an average of six to seven percentage points of GDP, a figure that is quite close to the world average and not very far from the nine or ten points seen in developed countries. ${ }^{2}$

The increase of almost four percentage points of GDP in social spending ought to improve risk coverage for the population, particularly the poorest. This is not inevitable, however, because spending is not always concentrated on the lowest-income sectors of society (table 2).

In the experience of the region, it has proved very difficult to target social spending on the poorest and/or widen population coverage. For this reason, social policy outcomes have not matched spending efforts. Systems of social security (and of social protection in general) have been confronted simultaneously with strong growth in the demand for services and a rise in their production costs. This growth in financing requirements is occurring in the midst of increased economic volatility and greater fiscal constraints in the countries, so that reform proposals need to aim simultaneously at improving efficiency and management techniques to hold down costs and at strengthening solidarity mechanisms, owing to the precarious levels of so many people's incomes.

Among the factors determining the demand for social security services, those associated with the business cycle can be distinguished from those deriving

\footnotetext{
${ }^{2}$ Although the difference is significant in per capita terms: while the developed countries spend almost US\$1,800 per capita per year, the countries of the region spend only US\$ 370 . In general, analysts find it hard to distinguish how much of this goes on investment and how much on current spending.
}

from more structural causes. The former are closely related to the economic growth rate and to macroeconomic and social policies, while the latter reflect demographic, epidemiological and technological aspects.

One of the main ways in which the business cycle affects social security systems is through its impact on the labour market. For as long as social security systems in the Latin American countries follow the Bismarckian model, access to social protection systems will be determined by the contractual status of the worker, and contribution schemes will thus depend on the dynamics of the labour market. Changes in this market affect not just the demand for social services, but also the financing sources used to meet this demand. With current schemes, for example, the fact that most work is done in the informal sector has limited the scope for universalizing social security and using wage contributions as a principal source of financing.

Latin American labour markets did not develop favourably in the 1990s or the first two years of the 2000s. The key developments have been the way in which the countries' economies have adjusted to external shocks, and the weakness and volatility of growth rates, making it difficult to create jobs for an economically active population that is growing as a result of demographic inertia and increased participation by women in the workforce. In fact, macroeconomic policy in most of the region's countries has been strongly procyclical, while its capacity for using fiscal, monetary and exchange-rate instruments to adjust to real or financial shocks from outside has diminished. Consequently, the burden of adjustment has fallen increasingly on labour markets in the form of higher levels of unemployment and informal working. Vulnerability to unemployment has thus increased, as has job turnover (a characteristic of private-sector employment), and a larger proportion of workers are 
TABLE 1

Latin America: Total public-sector social spending

(Percentages of GDP)

\begin{tabular}{|c|c|c|c|c|c|c|}
\hline & 1990-1991 & $1992-1993$ & 1994-1995 & 1996-1997 & 1998-1999 & 2000-2001 \\
\hline Latin America & 10.4 & 11.3 & 12.0 & 12.3 & 13.1 & 14.1 \\
\hline Argentina & 19.3 & 20.1 & 21.1 & 20.0 & 20.8 & 21.6 \\
\hline Bolivia & $\ldots$ & $\ldots$ & 12.4 & 1.6 & 16.3 & 17.9 \\
\hline Brazil & 18.1 & 17.7 & 19.3 & 17.3 & 19.3 & 18.8 \\
\hline Chile & 11.7 & 12.4 & 12.3 & 13.0 & 14.7 & 16.0 \\
\hline Colombia & 6.8 & 8.1 & 11.5 & 15.3 & 14.0 & 13.6 \\
\hline Costa Rica & 15.6 & 15.2 & 15.8 & 16.8 & 16.4 & 18.2 \\
\hline Ecuador & 5.5 & 5.8 & 7.4 & 8.2 & 8.1 & 8.8 \\
\hline El Salvador & $\ldots$ & 3.1 & 3.4 & 3.8 & 4.1 & 4.2 \\
\hline Guatemala & 3.4 & 4.1 & 4.1 & 4.3 & 6.0 & 6.2 \\
\hline Honduras & 7.9 & 8.1 & 7.8 & 7.2 & 7.5 & 10.0 \\
\hline Mexico & 6.5 & 8.1 & 8.8 & 8.5 & 9.2 & 9.8 \\
\hline Nicaragua & 11.1 & 10.9 & 12.2 & 11.3 & 13.0 & 13.2 \\
\hline Panama & 18.6 & 19.5 & 19.8 & 20.9 & 21.6 & 25.5 \\
\hline Paraguay & 3.1 & 6.2 & 7.0 & 8.0 & 8.5 & 8.5 \\
\hline Peru & 4.0 & 5.3 & 6.7 & 7.1 & 7.7 & 8.0 \\
\hline Dominican Rep. & 4.3 & 5.9 & 6.1 & 6.0 & 6.6 & 7.6 \\
\hline Uruguay & 16.9 & 18.9 & 20.3 & 21.3 & 22.8 & 23.5 \\
\hline Venezuela & 8.5 & 8.9 & 7.6 & 8.3 & 8.4 & 11.3 \\
\hline
\end{tabular}

Source: ECLAC, on the basis of official figures.

TABLE 2

\section{Latin America: Change in per capita social spending, and percentage going to the first quintilea \\ (Percentages)}

\begin{tabular}{|c|c|c|c|c|c|c|c|c|}
\hline \multirow[t]{2}{*}{ Country } & \multicolumn{2}{|c|}{ Education } & \multicolumn{2}{|c|}{ Health and nutrition } & \multicolumn{2}{|c|}{ Social security } & \multicolumn{2}{|c|}{ Housing, water, sanitation and others } \\
\hline & $\begin{array}{c}\text { Percentage } \\
\text { increase } \\
\text { over decade }\end{array}$ & $\begin{array}{c}\text { Percentage } \\
\text { going to } \\
\text { poorest } 20 \%\end{array}$ & $\begin{array}{l}\text { Percentage } \\
\text { increase } \\
\text { over decade }\end{array}$ & $\begin{array}{c}\text { Percentage } \\
\text { going to } \\
\text { poorest } 20 \%\end{array}$ & $\begin{array}{l}\text { Percentage } \\
\text { increase } \\
\text { over decade }\end{array}$ & $\begin{array}{c}\text { Percentage } \\
\text { going to } \\
\text { poorest } 20 \%\end{array}$ & $\begin{array}{l}\text { Percentage } \\
\text { increase } \\
\text { over decade }\end{array}$ & $\begin{array}{c}\text { Percentage } \\
\text { going to } \\
\text { poorest } 20 \%\end{array}$ \\
\hline Average & 37.2 & 27.9 & 25.2 & 26.9 & 37.4 & 15.0 & 20.4 & 22.1 \\
\hline Argentina & 41.0 & 32.5 & 28.7 & 38.7 & 20.9 & 11.0 & 30.1 & 20.5 \\
\hline Brazil $^{b}$ & 13.9 & 30.1 & 4.9 & 31.5 & 36.6 & 42.0 & -10.3 & 30.8 \\
\hline Chile & 56.9 & 34.0 & 52.4 & 30.9 & 39.5 & 4.0 & 48.9 & 37.3 \\
\hline Colombia & 48.3 & 21.4 & 77.9 & 17.5 & 54.5 & $\ldots$ & 53.8 & $\ldots$ \\
\hline Costa Rica & 29.4 & 15.7 & 17.1 & 2.7 & 31.0 & 7.1 & 1.6 & $\ldots$ \\
\hline Guatemala & 40.0 & $\ldots$ & 36.4 & $\ldots$ & 25.0 & $\ldots$ & 93.3 & $\ldots$ \\
\hline Honduras & -3.1 & $\ldots$ & -25.0 & $\ldots$ & $\ldots$ & $\ldots$ & 40.0 & $\ldots$ \\
\hline Mexico & 37.7 & $\ldots$ & -28.0 & $\ldots$ & 89.3 & $\ldots$ & 35.0 & $\ldots$ \\
\hline Nicaragua & 15.4 & $\ldots$ & 0.0 & $\ldots$ & $\ldots$ & $\ldots$ & 50.0 & $\ldots$ \\
\hline Panama & 36.9 & $\ldots$ & 2.6 & $\ldots$ & 13.4 & $\ldots$ & -26.2 & $\ldots$ \\
\hline Paraguay & 66.7 & $\ldots$ & 73.7 & $\ldots$ & 54.3 & $\ldots$ & -300.0 & $\ldots$ \\
\hline Peru & 54.8 & $\ldots$ & 60.5 & $\ldots$ & 71.3 & $\ldots$ & 78.6 & $\ldots$ \\
\hline Dominican Rep. & 70.2 & $\ldots$ & 51.6 & $\ldots$ & 62.5 & $\ldots$ & 16.1 & $\ldots$ \\
\hline Uruguay & 40.4 & 33.2 & 18.2 & 34.9 & 46.4 & 12.4 & 51.5 & 14.1 \\
\hline Venezuela & 7.9 & $\ldots$ & -16.3 & $\ldots$ & 5.3 & $\ldots$ & -100.0 & $\ldots$ \\
\hline
\end{tabular}

Source: ECLAC (2001b), tables IV.5 and IV.7.

a The percentage increases are estimated in relation to the value at the end of the period.

b The education figures are for primary only. Social security includes only pensions. The estimate is for consolidated social spending. 
TABLE 3

Latin America and the Caribbean: Urban unemployment ${ }^{a}$

(Average annual rates)

\begin{tabular}{|c|c|c|c|c|c|c|c|c|c|c|c|c|}
\hline & Area & 1990 & 1993 & 1994 & 1995 & 1996 & 1997 & 1998 & 1999 & 2000 & 2001 & 2002 \\
\hline \multicolumn{12}{|l|}{ Latin America and } & 9.0 \\
\hline $\begin{array}{l}\text { Simple average } \\
\text { for } 22 \text { countries }\end{array}$ & & $\cdots$ & 10.0 & 9.5 & 10.1 & 10.5 & 9.9 & 9.7 & 10.3 & 10.1 & 10.3 & \\
\hline \multicolumn{13}{|l|}{ Latin America } \\
\hline Argentina & UA & 7.4 & 9.6 & 11.5 & 17.5 & 17.2 & 14.9 & 12.9 & 14.3 & 15.1 & 17.4 & 19.7 \\
\hline Bolivia & $\mathrm{DC}$ & 7.3 & 5.8 & 3.1 & 3.6 & 3.8 & 4.4 & 6.1 & 8.0 & 7.5 & 8.5 & \\
\hline Brazil & $6 \mathrm{MA}$ & 4.3 & 5.4 & 5.1 & 4.6 & 5.4 & 5.7 & 7.6 & 7.6 & 7.1 & 6.2 & 7.1 \\
\hline Chile & NT & 7.8 & 6.5 & 7.8 & 7.4 & 6.4 & 6.1 & 6.4 & 9.8 & 9.2 & 9.1 & 9.0 \\
\hline Colombia & 7MA & 10.5 & 8.6 & 8.9 & 8.8 & 11.2 & 12.4 & 15.3 & 19.4 & 17.2 & 18.2 & 17.6 \\
\hline Costa Rica & UT & 5.4 & 4.0 & 4.3 & 5.7 & 6.6 & 5.9 & 5.4 & 6.2 & 5.3 & 5.8 & 6.8 \\
\hline Cuba & NT & $\ldots$ & 6.2 & 6.7 & 7.9 & 7.6 & 7.0 & 6.6 & 6.0 & 5.5 & 4.1 & 3.5 \\
\hline Ecuador & UT & 6.1 & 8.9 & 7.8 & 7.7 & 10.4 & 9.3 & 11.5 & 15.1 & 14.1 & 10.4 & 8.6 \\
\hline El Salvador & UT & 10.0 & 8.1 & 7.0 & 7.0 & 7.5 & 7.5 & 7.6 & 6.9 & 6.5 & 7.0 & 7.1 \\
\hline Guatemala & NT & 6.3 & 2.6 & 3.5 & 3.9 & 5.2 & 5.1 & 3.8 & $\ldots$ & $\ldots$ & $\ldots$ & $\ldots$ \\
\hline Honduras & UT & 7.8 & 7.0 & 4.0 & 5.6 & 6.5 & 5.8 & 5.2 & 5.3 & $\ldots$ & 6.3 & 6.2 \\
\hline Mexico & UA & 2.7 & 3.4 & 3.7 & 6.2 & 5.5 & 3.7 & 3.2 & 2.5 & 2.2 & 2.5 & 2.7 \\
\hline Nicaragua & NT & 7.6 & 17.8 & 17.1 & 16.9 & 16.0 & 14.3 & 13.2 & 10.7 & 9.8 & 10.7 & 12.9 \\
\hline Panama & MR & 20.0 & 15.6 & 16.0 & 16.6 & 16.9 & 15.5 & 15.2 & 14.0 & 15.2 & 16.9 & 16.1 \\
\hline Paraguay & UT & 6.6 & 5.1 & 4.4 & 5.3 & 8.2 & 7.1 & 6.6 & 9.4 & 10.0 & 10.8 & $\ldots$ \\
\hline Peru & ML & 8.3 & 9.9 & 8.8 & 8.2 & 8.0 & 9.2 & 8.5 & 9.2 & 8.5 & 9.3 & 9.4 \\
\hline Dominican Rep. & NT & $\ldots$ & 19.9 & 16.0 & 15.8 & 16.5 & 15.9 & 14.3 & 13.8 & 13.9 & 15.6 & 16.1 \\
\hline Uruguay & UT & 8.5 & 8.3 & 9.2 & 10.3 & 11.9 & 11.5 & 10.1 & 11.3 & 13.6 & 15.3 & 17.0 \\
\hline Venezuela & NT & 10.4 & 6.6 & 8.7 & 10.3 & 11.8 & 11.4 & 11.3 & 14.9 & 14.0 & 13.4 & 15.9 \\
\hline \multicolumn{13}{|l|}{ Caribbean } \\
\hline Barbados & NT & 14.7 & 24.3 & 21.9 & 19.7 & 15.6 & 14.5 & 12.3 & 10.4 & 9.2 & 9.9 & 10.5 \\
\hline Jamaica & NT & 15.3 & 16.3 & 15.4 & 16.2 & 16.0 & 16.5 & 15.5 & 15.7 & 15.5 & 15.0 & $\ldots$ \\
\hline Trinidad and Tobago & NT & 20.1 & 19.8 & 18.4 & 17.2 & 16.2 & 15.0 & 14.2 & 13.1 & 12.8 & 11.1 & 11.0 \\
\hline
\end{tabular}

Source: ECLAC (2002a).

a UA: urban areas; NT: national total; DC: departmental capitals; MA: metropolitan areas; UT: urban total; ML: metropolitan Lima; MR: metropolitan region. The simple averages for 1999, 2000 and 2001 are adjusted to compensate for missing data. The figures for all Latin America in the first halves of 2001 and 2002 are weighted averages for the countries with information available.

not covered for risks, because many jobs are informal ones that provide no social protection. ${ }^{3}$

The average unemployment rate in the region showed a rising trend in the 1990 s, peaking at $9 \%$ in 2002. Similarly, employment-output elasticity has tended

\footnotetext{
${ }^{3}$ Tokman (2003) identifies three factors that were instrumental in shifting the burden of adjustment on to the labour market: i) the reforms introduced to extend the grounds for dismissal and reduce adjustment times for companies, compounded by asymmetries that placed a large part of the economic adjustment burden on employment; ii) privatization, which has helped shift job creation from the public to the private sector, and iii) a shift in the privatesector employment structure towards informal and service-sector jobs and those without contracts or social protection.
}

to decline, so that higher growth rates are required to generate new jobs. Along with this fall in elasticity, job security and benefits have tended to deteriorate owing to the growing importance of informal employment (table 4). According to estimates by the International Labour Organization (ILO), seven out of every ten jobs were generated in the informal sector in the 1990s.

All this means that unemployment insurance will play an important role in the future, not only as a stabilizer of internal income but as an important source of financing for any social security scheme. ${ }^{4}$

\footnotetext{
${ }^{4}$ This paper will not concern itself with unemployment risk except insofar as it limits the extension of social protection cover. See Velásquez (2003) for a recent analysis of unemployment insurance.
} 
TABLE 4

Latin America: Structure of non-agricultural employment (Percentages)

\begin{tabular}{|c|c|c|c|c|c|}
\hline & \multirow{3}{*}{ Total } & \multicolumn{4}{|c|}{ Employed } \\
\hline & & \multicolumn{2}{|c|}{ Informal sector } & \multicolumn{2}{|c|}{ Formal sector } \\
\hline & & 1990 & 2001 & 1990 & 2001 \\
\hline Latin America & 100 & 42.8 & 46.3 & 57.2 & 53.7 \\
\hline Argentina & 100 & 52.0 & 45.7 & 48.0 & 54.3 \\
\hline Brazil & 100 & 40.6 & 46.0 & 59.4 & 54.0 \\
\hline Chile & 100 & 37.9 & $38.0^{\mathrm{a}}$ & 62.1 & $62.0^{\mathrm{a}}$ \\
\hline Colombia & 100 & 45.7 & 55.6 & 54.3 & 44.4 \\
\hline Costa Rica & 100 & 41.2 & 44.9 & 58.8 & 55.1 \\
\hline Ecuador & 100 & 55.6 & 57.4 & 44.4 & 42.6 \\
\hline Honduras & 100 & 57.6 & $60.7^{b}$ & 42.4 & $39.2^{\mathrm{b}}$ \\
\hline Mexico & 100 & 38.4 & 39.6 & 61.6 & 60.4 \\
\hline Panama & 100 & 36.0 & $37.3^{\mathrm{a}}$ & 64.0 & $62.7^{a}$ \\
\hline Peru & 100 & 52.7 & 59.5 & 47.3 & 40.5 \\
\hline Uruguay & 100 & 39.1 & 42.2 & 60.9 & 57.8 \\
\hline Venezuela & 100 & 38.6 & 49.2 & 61.4 & 50.8 \\
\hline
\end{tabular}

Source: ILO (2002).

a 2000 figure.

b 1999 figure.

One significant factor affecting the labour market and the design of social security systems is the need for technological change and greater competitiveness resulting from participation in the international economy. The need to adapt the production structure to a situation in which economies have opened up internationally means that greater labour mobility is required among the different production sectors, so that the new production requirements can be met.

Although desirable, increased labour mobility among sectors and greater competitiveness should not be achieved at the expense of social security. On the contrary, one challenge for the reforms is to reconcile the mechanisms and costs of insurance with the needs of labour mobility and competitiveness. Insofar as social protection systems facilitate labour mobility among competitive production sectors, they will improve the capacity of the labour market to respond to external shocks. What is required for this, particularly where health and pensions are concerned, are portable social security benefits financed from assets acquired at competitive costs.

The increased volatility observed in the business cycle has brought with it greater instability in income levels, resulting in a higher percentage of persons facing social and economic risk. This has meant both a reduction in people's capacity to pay contributions and an increase in the demand for insurance and social protection. Under these circumstances, social security systems need to reconcile the functions of insurance, to cope with the increase in economic risk, with those of distribution and solidarity, to be able to provide universal cover against those risks.

It is here that the level and composition of public spending, especially in the area of social protection, can serve to stabilize internal income levels and thus act as insurance against social risks in economies exposed to powerful and frequent external shocks. Rodrik (1998) shows a positive correlation between the international integration of an economy and the size of the State. In other words, the greater the degree of international openness, the higher public spending is found to be, whether for consumption or for social security. $^{5}$

The main macroeconomic advances in the 1990s include the consolidation of fiscal accounts and the fall in inflation. Where fiscal adjustment is concerned, the deficit held steady for most of the decade at an average of some $1.6 \%$ of GDP, although during the recent crisis (1997-2002), when the severity of certain countries' fiscal problems came to light, it rose to figures in excess of $3 \%$ of GDP. Success in keeping the fiscal deficit down to moderate levels has proved consistent, however, with a recovery in public expenditure levels (tables 1 and 5).

Despite the fiscal achievements, procyclical management of tax policy has adversely affected the ability of countries to finance social security services when demand for them has risen in periods of recession. The evolution of social spending has followed the vagaries of economic growth, so that the loss of revenue during downturns has prevented coverage from being expanded (or maintained) by means of increased fiscal spending. If it is to underpin social protection policy, therefore, macroeconomic policy needs to concern itself not just with smoothing out business cycles but also with producing fiscal expenditure rules that provide scope for countercyclical public spending. This being so, rules to link fiscal goals with structural parameters rather than temporary conditions in the economy are an important element in social policy. This is particularly true in the new climate of vulnerability and volatility within which the Latin American economies now operate.

\footnotetext{
5 The degree of economic openness is measured by the ratio of exports and imports to GDP.
} 
TABLE 5

Latin America and the Caribbean: Economic indicators

\begin{tabular}{|c|c|c|c|c|c|c|c|c|c|c|c|}
\hline & 1992 & 1993 & 1994 & 1995 & 1996 & 1997 & 1998 & 1999 & 2000 & 2001 & 2002 \\
\hline \multicolumn{12}{|l|}{ Gross domestic product } \\
\hline (annual rate of change) & 3.0 & 3.3 & 5.2 & 1.1 & 3.7 & 5.1 & 2.2 & 0.5 & 3.8 & 0.3 & -0.5 \\
\hline \multicolumn{12}{|l|}{ Public-sector balance } \\
\hline (\% of GDP) & -1.4 & -1.4 & -1.8 & -1.5 & -1.5 & -1.4 & -2.4 & -2.8 & -2.5 & -3.2 & -3.3 \\
\hline \multicolumn{12}{|l|}{ Consumer price index } \\
\hline (December on December) & 414.4 & $\begin{array}{c}872.4 \\
(898.3)\end{array}$ & $\begin{array}{c}328.7 \\
(340.9)\end{array}$ & $\begin{array}{c}26.0 \\
(25.9)\end{array}$ & $\begin{array}{c}18.6 \\
(18.6)\end{array}$ & $\begin{array}{c}10.7 \\
(10.3)\end{array}$ & $\begin{array}{r}10.0 \\
(9.8)\end{array}$ & $\begin{array}{r}9.7 \\
(9.5)\end{array}$ & $\begin{array}{c}9.0 \\
(8.6)\end{array}$ & $\begin{array}{c}6.1 \\
(5.9)\end{array}$ & $\begin{array}{c}11.4 \\
(12.2)\end{array}$ \\
\hline \multicolumn{12}{|l|}{ Total public spending } \\
\hline (\% of GDP) & 17.5 & 17.8 & 18.0 & 18.2 & 18.1 & 18.6 & 19.3 & 20.5 & 20.6 & 19.8 & $\ldots$ \\
\hline $\begin{array}{l}\text { Public-sector social } \\
\text { spending ( } \% \text { of GDP) }\end{array}$ & 10.9 & 11.9 & 12.1 & 12.1 & 12.4 & 12.5 & 12.7 & 13.4 & $\ldots$ & $\ldots$ & $\ldots$ \\
\hline
\end{tabular}

Source: ECLAC (2002b) and, for figures in brackets, ECLAC (2003).

Where social protection is concerned, structural changes can be foreseen that owe nothing to the business cycle and are likely to lead to a substantial increase in the demand for social services. These include population ageing, changes in epidemiological characteristics, technological changes (particularly in the area of health) and changes in the structure of households.

\section{III}

\section{Health and pension reforms}

It is common for social protection systems to have to cope with serious discrepancies between the financial resources needed and the funding actually available to meet demand. The result is that cost constraint is a key element in any effort to reform systems, even in industrialized economies that set out from a system of social protection with universal coverage. In Latin America the situation is more serious, as cost constraint is not the only challenge for reform. The need to bring large sections of the population into social security systems makes it essential to move towards a universality of benefits. Consequently, both efficiency and solidarity are essential parts of any reform agenda.

This is why the relationship between financing and provision of benefits is so important in Latin American reforms. It will not only affect the working of health and pension systems but, as efforts are made to extend coverage to sectors unable to contribute, will also have a major effect on the public finances. For this reason, any reform strategy needs to consider not only the financial constraints imposed by the macroeconomy, but also the major repercussions that the implemented design may have on the demand for fiscal resources, and thence on the fiscal accounts.

This is of vital importance, since reforms in most of the region's countries envisage major changes in the public-private mix, with greater private-sector involvement in managing the financing of contributory regimes and service provision. How the public-private mix is configured in social security systems affects the distributive function of the State. To attain objectives of equity, solidarity and efficiency, then, it is necessary to improve existing institutions and/or create new ones, and this will have a significant effect on the financial needs of the public sector.

\section{Reforms to health system financing}

\section{a) The organization of financing}

In the case of health systems, the international evidence shows that spending more does not always bring better results. The United States spends about 13\% of GDP on health care, and its population coverage and health indicators are worse than those of the other 
countries of the Organisation for Economic Cooperation and Development (OECD), which spend an average of some $8 \%$ or $9 \%$ of GDP. This suggests that the way the financing and provision of health services are organized has a strong influence on demand for resources in the sector and on the results obtained (White, 1995).

For this reason, one of the main challenges for the reforms has been to create appropriate rules and institutional arrangements for financing, and to find the right way to tie financing to service provision (Londoño and Frenk, 1997). Broadly speaking, there has been a growing consensus on the advantages of separating financing and provision. Concerning financing, and given that the economic environment is increasingly uncertain and that the demand for health services has a large aleatory component characterized by the uncertainty and diversity of risks, social insurance has become an efficient way of organizing the financing of health services (Buti, Franco and Pench, 2000).

Social health insurance needs to reconcile the functions of insurance with those of solidarity, distribution and universal coverage, and do so irrespective of people's employment situation. To achieve this, it is necessary to devise rules for insurance premiums, financing sources, the degree and level of benefits and coverage offered, the population universe included, and eligibility criteria. How all this is resolved will greatly affect the amount of financing that the health sector will require from the rest of society, the degree to which the insurance and solidarity functions are integrated, and the characteristics of the publicprivate dynamic in financial management and service provision.

In a social insurance context, irrespective of whether such insurance is operated by public- and/or private-sector managers, insurance functions have to be reconciled with those of distribution if progress is to be made towards universal coverage. ${ }^{6}$ The cost of the premium per subscriber should be based not on risks reflecting individual factors (such as age, sex or medical history) but on the collective risks affecting the population as a whole. This implies subsidies to cover the cost of premiums, so that people will have access to the benefits offered by the insurance regardless of their individual risks and their ability to pay. The result

\footnotetext{
${ }^{6}$ The services concerned do not have to be provided by the public sector, but can perfectly well be operated by the private sector.
}

is solidarity between the sick and the well, between young and old, and between high and low earners.

In this context, private spending on health care should not be confused with private administration of funds in the social security system, as here it is public money that is being privately managed. Private spending on health care is that which is carried out outside the coverage of the social security system (socalled out-of-pocket expenses, copayments, etc.). The fact that such private spending is a large component of total health spending reflects the weakness of social protection systems. The greater the share of private health spending in the total, the more exclusive and inequitable health systems are (WHO, 2000).

When the structure of health spending in the Latin American countries is compared with that in the industrialized countries, the share of public spending is found to be much higher in the latter. This reflects the fact that their social health-care systems have comprehensive universal coverage. In Latin America and the Caribbean, on the other hand, private health spending was about $60 \%$ of the total in 1995 (tables 6 and 7).

\section{b) Solidarity in financing}

Progress towards greater population coverage involves higher subsidies to the sector, and thus greater demand for financial resources. Better social healthcare provision will require efficiency improvements, both in the allocation and management of resources so that services can be improved, and in income-related solidarity mechanisms, particularly cross-subsidies from high-income to low-income sectors. While efficiency improvements reduce costs and help lower the demand for financial resources, solidarity mechanisms tend to raise costs but enable the benefits

TABLE 6

Selected regions and countries: Public-sector health spending, 1995

\begin{tabular}{lccc}
\hline & & \multicolumn{2}{c}{ As percentage } \\
\cline { 3 - 4 } & $\begin{array}{c}\text { Spending per } \\
\text { capita (dollars) }\end{array}$ & Of GDP & $\begin{array}{c}\text { Of total } \\
\text { health spending }\end{array}$ \\
\hline Latin America and & & 3.0 & 41.5 \\
$\quad$ the Caribbean & 102 & 7.0 & 71.0 \\
Canada & 1314 & 6.6 & 76.2 \\
OECD & 1310 & 6.3 & 44.0 \\
United States & 1628 & & \\
\hline
\end{tabular}

Source: World Health Organization (WHO) data.

a Purchasing power parity. 
TABLE 7

Latin America and the Caribbean: Composition of total health spending (public and private sectors), by subsector, 1990 and 1995 (Percentages of total spending)

\begin{tabular}{llrr}
\hline & & \multicolumn{2}{c}{ Health spending } \\
\cline { 3 - 4 } & Subsector & 1990 & 1995 \\
\hline Public spending & & 43.4 & 41.5 \\
Central government & & 12.2 & 15.8 \\
Local government & & 7.4 & 8.5 \\
& Social security & 23.8 & 17.2 \\
Private spending & & 56.6 & 59.5 \\
& Direct & $\ldots$ & 39.0 \\
Total & Indirect & $\ldots$ & 19.5 \\
& & 100.0 & 100.0 \\
\hline
\end{tabular}

Source: Molina, Pinto and others (2000); for 1990, based on Suárez and others (1995); for 1995, based on PAHO/WHO (1998), table 54.

of social security to be extended to more people (Van de Ven and Van Vliet, 1992).

Solidarity among people with different income levels in a social risk insurance context is created by setting up solidarity funds to distribute subsidies that compensate for differences in individual risk (figure 1). Each individual contributes on the basis of earnings. Premiums are determined by average risk and cost, and insurance agencies receive payments that reflect their risk portfolios. This system implies that some people will contribute more than the average premium value and others less, depending on risk and income levels. The higher contributions of the former, combined with revenue from other taxes, provide the resources for the solidarity fund.

In a risk insurance context, this mechanism makes it possible to retain the principle of equivalence between contributions and benefits at the aggregate level, but introduces solidarity to the extent that insureds receive a benefits package that does not depend on their individual contributions: if a user's expected expenditure level is above the average, the difference will be covered by subsidies. This system also discourages risk selection, since although insureds pay according to their means, insurers' revenues depend on their risk portfolios, which in the final analysis are what determine the level of spending expected. ${ }^{7}$

\footnotetext{
${ }^{7}$ In the region, the Colombian reform includes funds of this type. The reform now being discussed in Chile includes the creation of a solidarity fund. In Europe, there have been experiences of this type in Belgium, Germany, the Netherlands and Switzerland. Israel also has a solidarity fund mechanism.
}

FIGURE 1

\section{Solidarity in an insurance context}

Turn income-based contributions into risk-adjusted payments

$\mathrm{C}=$ Contributions $/ \mathrm{IA}=$ Insurance Agency

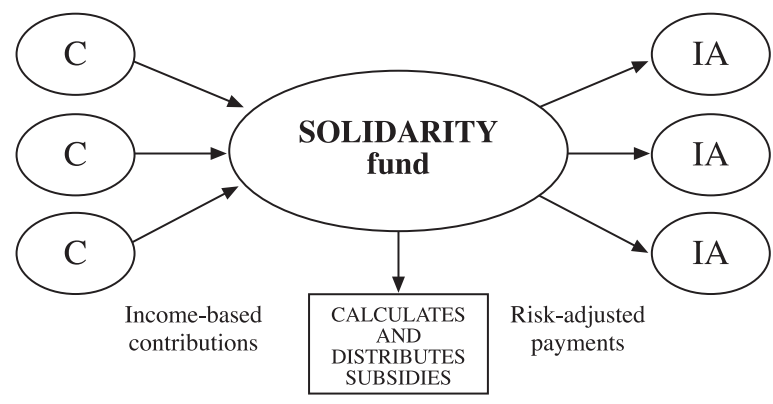

Source: Adapted from Titelman and Uthoff (2000).

The proportion of the population covered by social insurance also depends greatly on the source of financing. When insurance is financed exclusively out of wage contributions (which are the cornerstone of social security systems in most of the region's countries), they exclude those unable to contribute or the self-employed, who are covered mainly by the public-sector network of providers and, to a lesser extent, by the private sector. Any attempt to universalize the population coverage of insurance must involve widening the source of financing beyond compulsory employee contributions and compelling self-employed workers to contribute if they are in a position to do so. Furthermore, the contributions of those unable to pay must come out of general taxation. In this way, contributors and non-contributors can be linked by income solidarity mechanisms.

Given the budgetary constraints facing governments, it is important for compulsory contributions to be among the sources of solidarity financing. In Chile, for example, the bulk of health system contributions do nothing for income solidarity (only the $40 \%$ of contributions going into public-sector insurance are organized on this basis), so that the State has to obtain the resources from elsewhere. ${ }^{8}$ When compulsory contributions do not form part of solidarity financing,

\footnotetext{
${ }^{8}$ In Chile, compulsory social security contributions channelled through private insurance schemes are based on individual risk and there are no income solidarity mechanisms.
} 
the State has to take on a greater fiscal burden. If solidarity financing needs are high, this can place a great strain on the public budget.

An important issue, then, is the ability of those in the system to pay. As was seen in the introductory sections, the informal nature of the labour market in the region's countries has combined with an increasingly volatile business cycle to produce large shortfalls in contributions. This means, on the one hand, that large sections of the population have lost their insurance cover, with all the implied social costs. Again, hiatuses in employment have resulted in a low contribution density that is creating serious problems of financial sustainability in the insurance system. In a social risk insurance scheme, therefore, it is essential to have supplementary mechanisms that ensure a good contribution density, such as unemployment insurance or special insurance to cover contributions during spells of unemployment. Such supplementary insurance will inevitably create additional demand for fiscal resources or for supplementary insurance premiums (Velásquez, 2003).

\section{c) Guaranteed benefits and fiscal responsibilities}

One aspect that is the subject of great political and technical controversy, but that is central to the working of insurance systems and to the amount of financing required, is the content of the guaranteed benefits package. Although ethical, political, cultural and medical factors are all involved as well, we shall confine ourselves here to economic considerations.

Once society has decided on a set of entitlements that are enforceable by all social insurance subscribers, there automatically arises a financial obligation over time. If the social insurance is financed out of contributions and general taxation, the entitlement to benefits causes contingent liabilities to arise for the public sector. In other words, by creating an enforceable social entitlement, the State commits itself to guaranteeing this, which means that it is obliged to finance it over time.

To finance contingent liabilities, it is necessary to establish funding rules that guarantee provision of the benefits offered and meet the requirements of fiscal discipline so that public spending goals are met. In turn, the ability to finance contingent liabilities is seriously affected by the business cycle. One way of dealing with this is to use specific stabilization funds that build up resources during periods of economic growth and run them down at times of recession, so that the availability of financing is decoupled from immediate conditions in the economy. This call on public resources is in addition to the financial demands involved in achieving the contribution density that insurance systems require.

Changes in contingent liabilities over time also play a vital role in the financial sustainability of social insurance. For example, benefit entitlements should only be extended on the basis of rules and criteria that reconcile the increase in provision with the need to keep social expenditure trends within limits that are fiscally sustainable over time, and thus strengthen the actuarial components of social protection systems. ${ }^{9}$

\section{d) Public-private mix, efficiency and cost restraint}

Social insurance schemes that are to be administered by public- and private-sector insurers, and are to supply services through a network of public- and private-sector providers, need to be designed with care. A poorly conceived mix of public and private involvement in social security management results in inefficiencies in financial management and service provision, leading to greater pressure on public expenditure. The industrial organization of the sector is thus crucial to the design of any reform.

The experience of reform in Latin America and elsewhere suggests that a strong regulatory capability is required if the private sector is to be involved successfully in the health services market. The market failures that affect financing and provision mean that, in an unregulated or under-regulated market, privatesector involvement results in a loss of efficiency and equity. Where financing is concerned, the main problem for equity and efficiency is the possibility that insurers might be encouraged to carry out risk selection ("skimming off").

The Chilean experience illustrates this point. ${ }^{10}$ Private-sector insurers (ISAPRES) collect about $60 \%$ of compulsory social health insurance contributions. These institutions cater to only $25 \%$ of the population, however, and the public sector is responsible for the rest. When age and sex trends are observed, it transpires that the poorest and oldest, comprising the bulk of the riskiest population, tend to be in the public sector, while

\footnotetext{
${ }^{9}$ In setting benefits and entitlement rules, care needs to be taken not to create incentives for evasion. Otherwise the number of subsidized subscribers will tend to swell and the burden on the treasury or taxpayers to increase.

10 This does not imply that the Chilean model is the only one in the region that has problems with equity and efficiency. Given the underregulation of the current public-private mix, however, it offers a very good illustration of "skimming off".
} 
the ISAPRE sector covers the youngest, the healthiest and those with the highest incomes (tables 8 and 9).

As can be seen, the Chilean public-private mix concentrates coverage of the worst financial and health risks in the public sector, increasing the financial requirements of that sector. Yet most compulsory contributions go to the ISAPRE system, depriving the treasury of funding. Accordingly, the State is confronting a rising demand for health services, and its financial burden is increasing as a result. The situation has been compounded by a decline in contributions to the redistributive social security system from the highest-income population, and by implicit or explicit State subsidies for private health care.

The demand for higher funding in the health sector can also be offset greatly by efficiency improvements involving better management of resources and cost restraint in service provision. To achieve this, it is important to improve the management of public hospitals and the mechanisms whereby funding is allocated to providers (prospective budgeting and performance-related payments) and to make changes to the care model. Most spending in the region goes on curative rather than preventive care (table 10). One of the most effective ways of containing costs is to improve prevention, which means upgrading primary care networks.

\section{Pension system reforms}

\section{a) Organizing retirement saving}

Structural reforms to pension systems ${ }^{11}$ have brought about major changes in the relationship between benefits and contributions. Most reforms make greater or lesser use of individual capitalization schemes ("pillars"). ${ }^{12}$ The individual capitalization pillar may supplement or replace the unfunded pillar. In the region, efforts have been made to combine the new full individual capitalization pillars with the old unfunded pillars. There have been changeover systems that have shut down the public system and replaced it with a full individual capitalization one (Chile, 1979-1981; Mexico, 1995; Bolivia, 1996; El Salvador, 1996). There are mixed systems that include a full individual capitalization pillar as an integral part of a reformed public-sector pillar (Argentina, 1993; Uruguay, 1995). And there are parallel systems that have established a full individual capitalization pillar as an option in parallel with the reformed public-sector pillar (Peru, 1992; Colombia, 1993).

TABLE 8

Chile: Financing sources for the health sector, 2000

\begin{tabular}{lccr}
\hline & & Total & \\
\cline { 2 - 4 } & In billions of pesos & In billions of dollars & As \% \\
\hline Fiscal payments & 613221 & 1048 & 21.0 \\
Municipal payments & 38391 & 66 & 1.3 \\
Corporate payments & 184311 & 315 & 6.3 \\
Contributions & 1087216 & 1858 & 37.2 \\
Public & 444937 & 761 & 15.2 \\
Private & 642279 & 1098 & 22.0 \\
Out-of-pocket spending & 935923 & 1600 & 32.0 \\
Copayments & 315855 & 540 & 10.8 \\
Pharmacy & 288219 & 493 & 9.9 \\
Direct & 331849 & 567 & 11.4 \\
Other & 62522 & 106 & 2.1 \\
Total & 2921584 & 4933 & 100.0 \\
\hline
\end{tabular}

Source: Chilean Ministry of Health data.

\footnotetext{
${ }^{11}$ Non-structural reforms improve the solvency of the public pension system as a means of preserving it, and alter the benefits structure to adapt it to the contribution capacity of subscribers. Among other measures, these reforms have changed indexation rules, raised retirement ages, lowered the replacement rate, imposed stricter access conditions for disability and survivor's pensions and noncontributory pensions, abolished or restricted ex gratia or special pensions for public servants and increased the number of years' contributions required for pension entitlement (Mesa-Lago, 1999).
}

\footnotetext{
${ }^{12}$ These operate as individual saving accounts whose benefits depend on the contributions actually made, which are for set amounts and are capitalized in individual accounts. The value of the annuity is calculated from the sum capitalized by the subscriber up to retirement age, taking into account the life expectancy of the population. In the unfunded system, benefits were defined and contributions could vary in accordance with actuarial calculations; contributions were used to finance the defined benefits of subscribers, which were not linked to contributions and could be cross-subsidized.
} 
TABLE 9

Chile: Population distribution between the public health system and private health insurance institutions (Isapres), by age and household quintile, 2000

\begin{tabular}{|c|c|c|c|c|c|c|c|c|c|c|c|c|c|c|c|}
\hline \multirow[t]{2}{*}{ Age } & \multicolumn{3}{|c|}{ Quintile 1} & \multicolumn{3}{|c|}{ Quintile 2} & \multicolumn{3}{|c|}{ Quintile 3} & \multicolumn{3}{|c|}{ Quintile 4} & \multicolumn{3}{|c|}{ Quintile 5} \\
\hline & $\begin{array}{l}\text { Public } \\
\text { system }\end{array}$ & Isapres & Other & $\begin{array}{l}\text { Public } \\
\text { system }\end{array}$ & Isapres & Other & $\begin{array}{l}\text { Public } \\
\text { system }\end{array}$ & Isapres & Other & $\begin{array}{l}\text { Public } \\
\text { system }\end{array}$ & Isapres & Other & $\begin{array}{l}\text { Public } \\
\text { system }\end{array}$ & Isapres & Other \\
\hline $0-20$ & 85.4 & 5.5 & 9.1 & 69.9 & 16.6 & 13.5 & 54.4 & 28.0 & 17.6 & 36.6 & 42.7 & 20.7 & 19.1 & 66.1 & 14.8 \\
\hline $21-50$ & 81.8 & 6.1 & 2.1 & 67.6 & 16.4 & 16.1 & 54.4 & 26.6 & 19.1 & 37.9 & 40.4 & 21.7 & 21.8 & 60.1 & 18.1 \\
\hline $51-64$ & 87.3 & 2.9 & 9.8 & 81.8 & 6.0 & 12.3 & 72.4 & 12.1 & 15.5 & 59.6 & 20.3 & 20.1 & 37.1 & 39.8 & 23.2 \\
\hline 65 plus & 89.5 & 0.8 & 9.7 & 91.1 & 1.1 & 7.8 & 89.4 & 1.6 & 9.0 & 79.4 & 5.9 & 14.8 & 55.5 & 21.8 & 22.7 \\
\hline Total & 84.2 & 5.4 & 10.4 & 71.2 & 14.6 & 14.2 & 59.5 & 23.3 & 17.3 & 44.3 & 35.2 & 20.5 & 26.5 & 55.2 & 18.3 \\
\hline
\end{tabular}

Source: Titelman (2000).

TABLE 10

Latin America (eight countries): Distribution of health spending by service type, 1995

(Percentages)

\begin{tabular}{lccrr}
\hline Country & Preventive care & Curative care & Administration & Other \\
\hline Bolivia & 2.8 & 61.8 & 10.4 & 25.0 \\
Ecuador & 2.3 & 83.4 & 5.5 & 8.8 \\
El Salvador & 7.8 & 71.4 & 8.2 & 12.6 \\
Guatemala & 4.0 & 77.6 & 10.5 & 7.9 \\
Mexico & 9.0 & 80.0 & 3.0 & 8.0 \\
Nicaragua & 17.5 & 75.6 & 6.3 & 0.6 \\
Peru & 5.6 & 64.6 & 6.8 & 23.0 \\
Dominican Rep. & 7.4 & 67.0 & 15.5 & 10.1 \\
Average & 7.0 & 72.6 & 8.3 & 12.1 \\
\hline
\end{tabular}

Source: Molina, Pinto and others (2000), on the basis of studies of national accounts. Collaboration between the Pan American Health Organization (PAHO)/United States Agency for International Development (USAID)/Partnerships for Health Reform.

From a fiscal standpoint, the structure of the financing and calculation of pension system benefits in each of these reforms is not neutral. By changing the way benefits relate to contributions and by limiting the scope for cross-subsidy among contributors (leaving the State to finance the distributive function of the system), the reforms affect fiscal liabilities.

\section{b) Transition costs}

The State has to accept liability for the costs of the transition from one pillar to another (i.e., for entitlements acquired under previous contracts) that arise when contributions to unfunded public systems are turned into contributions to individual savings accounts.

How much this cost amounts to will depend on the contingent liabilities associated with the current and retired workforce, as determined by the contributions paid into the old system and the benefits accrued (Uthoff and Bravo, 1999; ECLAC, 1998). Their size can be estimated in the form of a debt equivalent to the present value of the future flow of benefits to which current pensioners are entitled, and as the present value of the future flow of benefits due to those currently in work who have contributed to the old system. Amortizing this debt requires complex actuarial calculations, but what results is a fiscal liability that will swell the social security deficit if not offset by fiscal financing. In Chile, this debt was financed partly by primary fiscal saving and partly by issuing bonos de reconocimiento, certificates of entitlement to benefits accrued under the old system. How and when this debt is financed will depend on how the transition from one system to the other is carried out. The authorities have to deal with the fiscal liabilities of transition both by reallocating spending and by increasing revenue.

After more than 20 years of reform, in which the changeover has gradually been made from an unfunded system to one of individual capitalization, the Chilean experience is illuminating. The reformed pension 


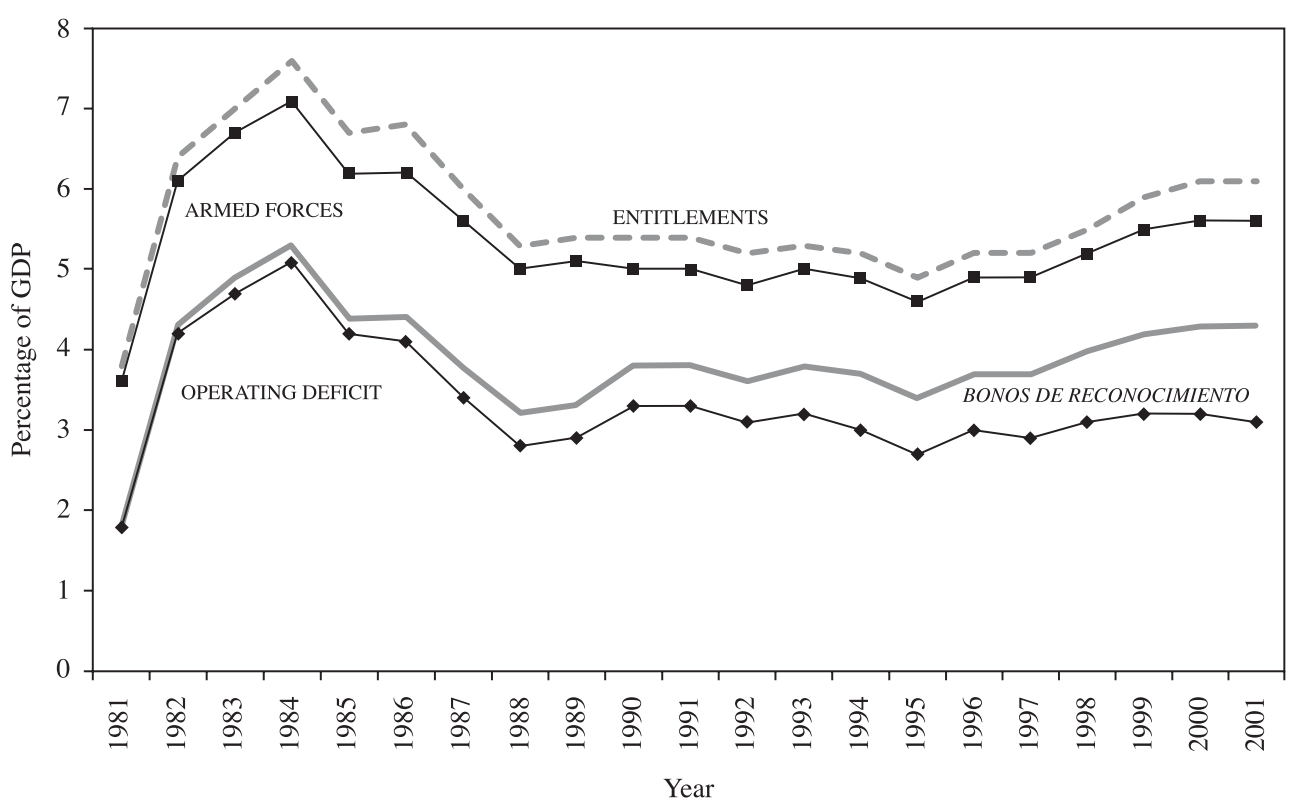

Source: Arenas de Mesa, 1999.

system has been sustained by an average increase in the social security deficit of some $2 \%$ of GDP during the first 20 years (Arenas de Mesa, 1999). This social security deficit (figure 2) breaks down into i) an operating deficit, reflecting payment of entitlements to those in retirement; ii) amortization of the bonos de reconocimiento, covering the entitlements of those who participated in the old system during their working lives; iii) payments to the armed forces pension systems, and iv) guaranteed social benefits to protect those who are indigent at retirement age (welfare pensions) and those who, having participated in the system, have not been able to build up enough capital for a socially acceptable benefit (minimum pensions).

The pension system debt to be made explicit can be large when a complete switch is made from an unfunded to a funded pillar, depending on demographic factors, the characteristics of coverage and eligibility conditions of the superseded systems, the entitlements that are established and the extent to which assets without ownership rights are replaced by assets that do carry such rights (Valdés, 2002). What part is made explicit and reflected in liabilities for the treasury, like those illustrated for Chile in figure 2, also depends on the reform strategy followed. To avoid very high operating costs and large liabilities in the form of bonos de reconocimiento, it is possible to take measures like the following before individually funded pillars are introduced as part of the reform: i) change benefit rules and eligibility conditions; ii) only partially introduce a full individually funded capitalization pillar and minimize the incentives to move to the new pillar; iii) or include defined-contribution and notional capitalization criteria for the unfunded systems as an intermediate step in the transition, as has been done in other cases. ${ }^{13}$

In most reforms, the extra fiscal burden has been difficult to accommodate. In Argentina, for example, the Government had to suspend indexation of the prestación compensatoria (a benefit to compensate for entitlements accrued by contributing to the old system) and also of the aporte medio previsional obligatorio (compulsory average pension contribution, or AMPO) legally mandated as the basis for calculating compensatory pensions. In Bolivia, the universal benefit for over-65s provided for by the bono solidario (solidarity bond, or BONOSOL) could not be covered;

\footnotetext{
${ }^{13}$ See Holzmann, 1997; ECLAC, 1998; Carvalho and Paiva, 2000; Fox and Palmer, 2001.
} 
although the benefit was extended to all over-50s, its value was reduced from US\$250 to US\$ 90 . In Chile, there has been extensive debate on the level of minimum pensions, owing to their impact on fiscal expenditure; as a way of controlling the spending they generate, welfare pensions (PASIS) are provided under a quota system which sets the maximum number that can be granted each year (Gana, 2002).

\section{c) Effects on the government budget}

The idea behind redistributive financing is to protect those whose contribution history does not entitle them to pensions of their own. The increased vulnerability of today's workers to unemployment, the scale of job turnover and the incidence of informal and insecure employment mean that fewer and fewer people are paying into contributory systems and contribution density is low. Financing for the pensions of those unable to generate savings of their own depends on income sources such as cross-subsidy and/or general taxation.

The scope for achieving solidarity through contributions diminishes when a full individual capitalization pillar is introduced. With this pillar, which is always in a state of actuarial balance, a subscriber's benefits are equivalent to his or her contributions, duly capitalized, and there are no cross-subsidies. With this scheme, those who save enough are insured and those who do not are underinsured. Application of the equivalence principle to the full individual capitalization pillar alone does not mean that those unable to contribute much might not receive cross-subsidies from those who can, within the reformed system. For this to happen, structural reforms to pension systems need to include a redistributive pillar to cover those workers. This pillar can be financed from increased fiscal subsidies and perhaps contributions. The basic problem with this combination of pillars is that, if extremely generous minimum and/or welfare benefits are provided, there will be no incentive for people to remain in the contributory pillars any longer than required for entitlement to the guaranteed benefits. It is indispensable, then, for such distortions to be corrected.

The coverage that a redistributive unfunded pillar should have and the way it is financed are major dilemmas for the current reforms. There is an extensive debate over how enforceable entitlements really are, whether they can be financed, and what incentives for avoidance and evasion might be created by noncontributory entitlements. One way of gauging the size of the redistributive pillar is to simulate a definedcontribution distributive pillar benefiting those who are excluded from the individual saving pillar. This is equivalent to having notional "solidarity accounts" for each citizen, for pension purposes.

Table 11 gives simulations for Chile of the present value of benefit payments guaranteed to current pensioners (row 1), future generations (row 2) and the total (row 3), and of the fiscal deficit flow involved in amortizing the total debt on a straight-line basis (last row).

TABLE 11

Chile: Simulation of contingent liabilities represented by entitlements, and fiscal deficit required to amortize them ${ }^{\mathrm{a}}$

(Percentages)

Entitlement as percentage

of the average wage in

the economy

Population covered by

entitlements as percentage

of EAP

Pensioners

Future generations

Total

Amortization of the debt

(fiscal deficit)
15

\begin{tabular}{rrr}
\hline & & \\
35 & \multicolumn{1}{c}{45} & \multicolumn{1}{c}{55} \\
\hline 5.2 & 6.7 & 8.1 \\
30.4 & 39.1 & 47.8 \\
35.6 & 45.8 & 56.9
\end{tabular}

20

\begin{tabular}{rrc}
\hline & & \\
35 & \multicolumn{1}{c}{45} & \multicolumn{1}{c}{55} \\
\hline 6.9 & 8.9 & 10.8 \\
40.5 & 52.1 & 63.7 \\
47.4 & 61.0 & 74.5
\end{tabular}

30

\begin{tabular}{ccc}
\hline & & \\
35 & 45 & 55 \\
\hline 10.3 & 13.3 & 16.2 \\
60.8 & 78.2 & 95.6 \\
70.1 & 91.5 & 111.8
\end{tabular}

Source: Prepared by the authors on the basis of demographic parameters, coverage, contribution rates and enforceable entitlements estimated at replacement rate.

a See Uthoff and Bravo (1999) for details of the methodology.

b EAP: economically active population. 
Latin America (four countries): Comparison of contingent liabilities represented by entitlements, and fiscal deficit required to amortize them

(Percentages)

\begin{tabular}{|c|c|c|c|}
\hline & \multicolumn{3}{|c|}{$\begin{array}{l}\text { Estimated for the } 45 \% \text { of the EAP entitled to a benefit, } \\
\text { at a replacement rate of } 20 \% \text { a }\end{array}$} \\
\hline & $\begin{array}{l}\text { Debt towards current generation } \\
\qquad(\% \text { of GDP })\end{array}$ & $\begin{array}{l}\text { Debt towards future generations } \\
\text { (\% of GDP) }\end{array}$ & $\begin{array}{l}\text { Fiscal deficit that would amortize } \\
\text { the debt (\% of GDP) }\end{array}$ \\
\hline Bolivia & 11.4 & 81.6 & 2.33 \\
\hline El Salvador & 9.5 & 63.2 & 1.82 \\
\hline Mexico & 8.7 & 62.0 & 1.77 \\
\hline Chile & 8.9 & 52.1 & 1.53 \\
\hline
\end{tabular}

Source: Prepared by the authors on the basis of demographic parameters, coverage, contribution rates and enforceable entitlements estimated at replacement rate.

a As percentage of average wage.

This method uses a discount rate equal to the rate of wage growth. The population entitled to guaranteed benefits is expressed as a percentage of the economically active population (EAP): $35 \%, 45 \%$ and $55 \%$. Benefits are expressed as percentages of the average wage in the economy (15\%, 20\% and 30\%). Given the simplifying assumptions, ${ }^{14}$ each of them has to be matched by an actuarially balanced contribution rate. With these suppositions, social security deficits for the welfare and minimum pensions of those currently retired, which now represent $0.4 \%$ of GDP (figure 2), will increase to $1.5 \%$ of GDP once the generations now working retire. Calculations by Arenas de Mesa (1999) for similar benefits (minimum pension) yielded comparable results. The calculations show that the percentage of the population entitled to guaranteed benefits and the replacement rate and/or notional contribution rate used to quantify their entitlements have a significant influence in determining contingent liabilities.

Calculations of contingent liabilities associated with guaranteed benefits depend not only on the amount of the benefits, expressed for example as replacement rates for average wages in the economy and the population covered. They are also affected by structural factors associated with the potential ability of

\footnotetext{
14 Three simplifying assumptions are used: i) the percentage of the population eligible to receive guaranteed benefits remains unchanged over time; ii) the eligible working population accrues solidarity contributions from the age of 20 until retirement, at a rate that is actuarially correct to finance the guaranteed benefits; iii) the eligible population that is already in retirement receives a solidarity pension from the age of 60 , at a replacement rate that is actuarially balanced with the value of the benefits guaranteed (Uthoff and Bravo, 1999).
}

subscribers to finance their own pensions, something that is influenced in Latin America by the extent of informal work, expressed in this methodology by the share of the EAP accounted for by wage earners. Again, they vary with demographic factors such as the dependency ratio between over-60s and the 20 to 59year-old population and the average life expectancy of those currently over 60 . Since these factors vary greatly from one country to another, the cost of similar benefits may differ among them (table 12).

Acknowledging pension entitlements for those who are underinsured or uninsured with regard to the individual capitalization pillar, and quantifying the contingent liabilities their demand represents, implies spelling out how the individual capitalization and defined-contribution pillar may be supplemented by an unfunded defined-benefit system, and how much financing is needed to cover such people. There is currently a debate as to whether solidarity should be financed from a tax on work (contributions), general taxation or a mixture of the two. In any event, the existence of guaranteed benefits means that the design of new systems should be carefully analysed, so that if they include distributive pillars, these do not create incentives for evasion or avoidance of contributions. Care is also needed to see that the way they are financed does not affect employment, whether directly by increasing the cost of contributions or indirectly by creating fiscal imbalances and undermining the competitiveness of the economy (ILO, 2001b; Orszag and Stiglitz, 1999).

\section{d) Contribution density and contingent liabilities}

Ultimately, if people are to be able to use an individual saving plan system to smooth consumption 
TABLE 13

Latin America (eight countries): Indirect indicators of contribution density

(Percentages)

\begin{tabular}{|c|c|c|}
\hline Risk indicator & December 2001 & December 2002 \\
\hline \multicolumn{3}{|c|}{ Contribution density } \\
\hline \multicolumn{3}{|c|}{ Subscribers/EAP } \\
\hline Argentina & 54.3 & 55.4 \\
\hline Bolivia & 21.2 & 23.1 \\
\hline Chile & 108.1 & 111.8 \\
\hline Costa Rica & 53.8 & 69.3 \\
\hline El Salvador & 35.8 & 36.7 \\
\hline Mexico & 63.8 & 71.9 \\
\hline Peru & 25.5 & 27.2 \\
\hline Uruguay & 38.9 & 41.4 \\
\hline \multicolumn{3}{|c|}{ Contributors/subscribers } \\
\hline Argentina & 29.0 & 33.2 \\
\hline Bolivia & 47.0 & 46.9 \\
\hline Chile & 53.7 & 51.0 \\
\hline Costa Rica & $\ldots$ & $\ldots$ \\
\hline El Salvador & 53.2 & 47.6 \\
\hline Mexico & 44.7 & 41.7 \\
\hline Peru & 41.2 & 39.4 \\
\hline Uruguay & 53.2 & 45.1 \\
\hline \multicolumn{3}{|c|}{ Contributors/EAP } \\
\hline Argentina & 15.7 & 18.4 \\
\hline Bolivia & 9.9 & 10.8 \\
\hline Chile & 58.0 & 57.0 \\
\hline Costa Rica & $\ldots$ & $\ldots$ \\
\hline El Salvador & 19.0 & 17.4 \\
\hline Mexico & 28.5 & 30.0 \\
\hline Peru & 10.5 & 10.7 \\
\hline Uruguay & 20.7 & 18.7 \\
\hline
\end{tabular}

Source: AIOS (2002).

over their lives, it is necessary to project the amount and density of contributions made while they are enrolled in the system during their working years. This will determine whether they receive satisfactory benefits or not. With defined-contribution full individual capitalization pillars, the contribution density of individuals, which depends on their personal saving capacity, will largely determine whether they end their working lives fully insured, underinsured or uninsured. Again, if contribution density is not known in advance, it will be difficult to quantify the solidarity contributions that the State has to capitalize (contingent liabilities) to finance the guaranteed pension in an actuarially balanced way. ${ }^{15}$

\footnotetext{
15 Benefits may be different, as they vary with the contributions made from a welfare pension to a minimum pension for those who qualify as eligible contributors (Uthoff, 2002).
}

Contribution density is affected by different risks, such as those of disability and death, ${ }^{16}$ and by employment instability as manifested in changing levels of unemployment and informal work. In societies where there is no unemployment insurance and where informal workers contribute little, ${ }^{17}$ contingent liabilities are sensitive to changes in the business cycle. Using indicators from the International Association of Pension Funds' Supervisory Organisations, table 13 shows a number of countries in which the percentage of subscribers is low in relation to the EAP, indicating that coverage of the capitalization pillars is low as well. ${ }^{18}$ Again, the low proportion of subscribers actually paying in shows indirectly that contribution density may be relatively low. The lack of market instruments to ensure high contribution density is an obstacle to low-income sectors, in particular, benefiting from social protection in the absence of redistributive financing. Although there have been new initiatives to promote unemployment insurance, these are still at an early stage and do not take account of other forms of labour market adjustment such as rising informal activity, in which contribution density is usually low.

By and large, the evidence indicates that workers' contribution levels are closely linked to the structure of the labour market and are not greatly influenced by the poverty levels of the households they belong to. Informal working strengthens the factors working against high contribution density. The contribution rate for informal activities has been holding fairly steady at a rate much lower than that for formal activities. Table 14 illustrates the situation in Chile.

\footnotetext{
${ }^{16}$ Also, many people work on an own-account basis and opt for other types of saving that are more easily accessible should contingencies arise (Coraggio, 2003).

17 Because people have different needs over the life cycle that compete with saving for old age.

${ }^{18}$ Records of pension system subscribers and contributors leave much to be desired, as the former are sometimes double-counted and the contribution density of the latter is not measured. The Chilean authorities have treated this problem as one of vital importance. Contribution density has been shown to be much lower than was expected when the system was established, and there are large variations by sex and age group. In 2001, the average contribution density of individual capitalization system subscribers was $41 \%$, while the average for system contributors was 59\%. This means that over 12 months, subscribers and contributors actually only paid 4.9 and 7 months of contributions, respectively (Government of Chile, 2003).
} 
TABLE 14

Chile: Percentage of workers paying into the individual private capitalization system, by poverty level and labour market segment, 1992 and 2000

\begin{tabular}{|c|c|c|c|c|}
\hline & \multicolumn{2}{|c|}{ Poor } & \multirow[t]{2}{*}{ Not poor } & \multirow[t]{2}{*}{ Total } \\
\hline & Indigent & Not indigent & & \\
\hline \multicolumn{5}{|l|}{1992} \\
\hline \multicolumn{5}{|l|}{ Informal sector } \\
\hline Domestic service & 21.5 & 22.6 & 42.8 & 37.5 \\
\hline Other & 21.1 & 25.9 & 26.2 & 25.9 \\
\hline Formal sector & 64.0 & 72.0 & 76.4 & 75.1 \\
\hline Total & 43.3 & 52.1 & 55.6 & 54.5 \\
\hline \multicolumn{5}{|l|}{2000} \\
\hline \multicolumn{5}{|l|}{ Informal sector } \\
\hline Domestic service & 7.4 & 18.2 & 40.6 & 36.6 \\
\hline Other & 9.3 & 18.9 & 28.2 & 26.6 \\
\hline Formal sector & 43.5 & 67.5 & 79.5 & 77.8 \\
\hline Total & 25.9 & 45.3 & 59.7 & 54.5 \\
\hline
\end{tabular}

Source: ECLAC tabulations, using data from the Chilean National Socio-economic Survey (CASEN).

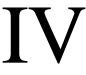

\section{Conclusions}

Reforms to social security systems involve the difficult task of reconciling entitlements and needs with financial constraints and shortfalls. Fiscal constraints limit the scope for financing the huge social demand in our countries. Again, the design and implementation of reforms have a significant impact on the demand for fiscal resources, as they affect the efficiency with which resources are allocated and managed, the way solidarity mechanisms are financed and the costs of transition.

Demand for social security services is influenced by cyclical economic factors and by variables of a more structural nature. It is largely through the labour market that the business cycle influences financing sources and the demands made on social security systems. The unfavourable evolution of the labour market in the countries of Latin America has created greater challenges for social security reform.

In economic environments characterized by greater uncertainty and volatility, and thus by higher social risk, social security reforms need to reconcile the functions of insurance and saving with those of redistribution and solidarity. This is crucial if the idea is to move towards universal coverage and benefits.

In the case of the health sector, social insurance is becoming an efficient way to organize financing. To move away from the current segmentation of the population among different health subsystems, membership of an insurance scheme needs to be decoupled from the occupational position of the individual. In other words, insurance needs to cover both employed and self-employed workers and those unable to contribute. This means establishing solidarity funds financed out of contributions and taxation. To the extent that social insurance management might involve private-sector administration of resources, it is vital to avoid the problems of risk selection. When private-sector administrators are involved in financing and providing social security services, it is crucial to have a good regulatory framework in place to ensure that these organizations have the same rights and duties as public-sector administrators.

Progress towards universal coverage in a social insurance context involves a number of financial demands 
on the public sector. The costs borne by the State may be very considerable, depending on the nature of the benefits covered by the insurance, the amounts of minimum and welfare pensions, the contribution density guarantee and the extent of subsidy for solidarity purposes.

As the benefits offered by social security systems turn into enforceable entitlements, they become contingent liabilities for the State and have to be financed irrespective of the vagaries of the business cycle. If it is to support social policy, macroeconomic policy needs to concern itself not just with smoothing out the business cycle, but also with creating fiscal expenditure rules that provide scope for countercyclical public spending. Rules to link fiscal goals with structural parameters rather than with the current position of the economy provide a good underpinning for social policy.

Another important issue is the calculation of contingent liabilities and their evolution over time. Such liabilities are affected by three factors. First, by the amount and volume of benefits guaranteed. Second, by significant changes over the business cycle in the number of people who can and cannot contribute, as problems stemming from low contribution density result in people who were apparently insured being left uninsured. Third, by the way solidarity is financed: if workers' and employers' contributions are not part of this, the cost for the treasury will tend to rise.

\section{Bibliography}

AIOS (International Association of Pension Funds' Supervisory Organizations) (2002): Boletín estadístico, No. 8, Buenos Aires, December.

Arenas de Mesa, A. (1999): Efectos fiscales del sistema de pensiones en Chile: proyección del déficit previsional: 1999-2037, article presented at the Seminar "Responsabilidades fiscales de los sistemas de pensiones" (ECLAC, Santiago, Chile, 2-3 September).

Arenas de Mesa, A. and J. Guzmán (2003): Política fiscal y protección social: sus vínculos en la experiencia chilena, Financiamiento del desarrollo series, No. 136, LC/L.1930-P, Santiago, Chile, ECLAC. United Nations publication, Sales No. S.03.II.G.86.

Barr, N. (2000): Reforming Pensions: Myths, Truths, and Policy Choices, IMF Working Paper, No. 139, Washington, D.C., August.

Buti, M., D. Franco and L.R. Pench (2000): Reconciling the Welfare State with Sound Public Finances and High Employment, working paper, Brussels, European Commission.

Carvalho, V. and S. Paiva (2000): Reforma previsional en Brasil. La nueva regla para el cálculo de los beneficios, Financiamiento del desarrollo series, No. 97, LC/L.1386-P, Santiago, Chile, ECLAC. United Nations publication, Sales No. S.00.II.G.62.

Coraggio, J.L. (2003): Sobrevivencia y otras estrategias en Latinoamérica y el Caribe: la perspectiva de lo local, Encuentro del Grupo Regional de Gestión de la Oficina Regional de las Américas y el Caribe, United Nations Children's Fund (UNICEF) (Havana, Cuba, 10 April).

ECLAC (Economic Commission for Latin America and the Caribbean) (1998): The Fiscal Covenant: Strengths, Weaknesses, Challenges, Libros de la CEPAL series, No. 47, LC/G.1997/Rev.1-P, Santiago, Chile. United Nations publication, Sales No. E.98.II.G.5.

(2001a): Crecer con estabilidad. El financiamiento del desarrollo en el nuevo contexto internacional, Bogota, ECLAC/Alfaomega.

(2001b): Social Panorama of Latin America, 2000-2001, LC/G.2138-P, Santiago, Chile. United Nations publication, Sales No. E.01.II.G.141. (2002a): Economic Surney of Latin America and the Caribean, 2001-2002, LC/G.2179-P, Santiago, Chile. United Nations publication, Sales No. E.02.II.G.02.

(2002b), Preliminary Overview of the Economies of Latin America and the Caribbean, 2002, LC/G.2196-P, Santiago, Chile. United Nations publication, Sales No. E.02.II.G.126.

(2003): Proyecciones de América Latina y el Caribe, 2003, Estudios estadísticos y prospectivas series, No. 19, LC/L.1886P, Santiago, Chile, April. United Nations publication, Sales No. S.03.II.G.52.

Fox, L. and E. Palmer (2001): Pension Reform in Europe in the 90's and Lessons for Latin America, Financiamiento del desarrollo series, No. 114, LC/L.1628-P, Santiago, Chile, ECLAC. United Nations publication, Sales No. E.01.II.G.166.

Gana, P.A. (2002): Las pensiones no contributivas en Chile: pensiones asistenciales (PASIS), in F. Bertranou, C. Solorio and W. Van Ginneken (eds.), Pensiones no contributivas y asistenciales, Santiago, Chile, International Labour Organization (ILO).

Government of Chile (2003): Observatorio laboral, Santiago, Chile, 9 May.

Holzmann, R. (1997): On Economic Benefits and Fiscal Requirements of Moving from Unfunded to Funded Pensions, Financiamiento del desarrollo series, No. 48, LC/L.1013, Santiago, Chile, ECLAC.

ILO (International Labour Organization) (2001a): Panorama laboral, 2001. América Latina y el Caribe, Lima, ILO Regional Office for Latin America and the Caribbean.

(2001b): Seguridad social: temas, retos y perspectivas. Informe IV, International Labour Conference, 89th meeting, Geneva, June.

Londoño, J.L. and J. Frenk (1997): Pluralismo estructurado: hacia un modelo innovador para la reforma de los sistemas de salud en América Latina, Salud y gerencia, No. 15, Bogota, Pontificia Universidad Javeriana, July-December.

Mesa-Lago, C. (1999): La reforma estructural de pensiones en América Latina: tipología, comprobación de presupuestos y enseñanzas, Pensiones en América Latina. Dos décadas de reforma, second edition, Lima, International Labour Organization (ILO). 
Molina, R., M. Pinto and others (2000): Health spending and financing: the current situation and trends, Pan American Journal of Public Health, vol. 8, No. 1-2, Washington, D.C., Pan American Health Organization (PAHO), July-August.

Orszag, P. and J. Stiglitz (1999): Rethinking pension reform: ten myths about social security systems, in R. Holzmann and J. Stiglitz (eds.), New Ideas about Old-Age Security, Washington, D.C., World Bank, September.

PAHO/WHO (Pan American Health Organization/World Health Organization) (1998), Health in the Americas, 1998, Washington, D.C.

Rodrik, A. (1998): Where has all the growth gone? External shocks, social conflict, and growth collapses, Journal of Economic Growth, No. 4, Boston, Kluwer Academic Publishers.

(2001): Why is there so much economic insecurity in Latin America?, CEPAL Review, No. 73, LC/G.2130-P, Santiago, Chile, April.

Suárez, R. and others (1995): Gasto en salud y financiamiento. América Latina y el Caribe, Desafíos para la década de los noventa, Washington, D.C., Pan American Health Organization/World Health Organization, unpublished.

Titelman, D. (2000): Reformas al sistema de salud en Chile: desafios pendientes, Financiamiento del desarrollo series, No. 104, LC/ L.1425-P, Santiago, Chile, ECLAC, September. United Nations publication, Sales No. S.00.II.G.99.

Titelman, D. and A. Uthoff (2000): El mercado de la salud y las reformas al financiamiento de los sistemas de salud, in D. Titelman and A. Uthoff (eds.), Ensayos sobre el financiamiento de la seguridad social en salud. Los casos de Estados Unidos, Canadá, Argentina, Chile, Colombia, Santiago, Chile, Fondo de Cultura Económica/ECLAC.
Tokman, V. (2003): Hacia una visión integrada para enfrentar la inestabilidad y el riesgo, Financiamiento del desarrollo series, No. 127, LC/L.1877-P, Santiago, Chile, ECLAC. United Nations publication, Sales No. S.03.II.G.44.

United Nations (2002): Social Protection, Bulletin on the eradication of powerty, No. 8, New York, Social Policy and Development Division.

Uthoff, A. (2002): Labour markets and pension systems, CEPAL Review, No 78, LC/G.2187-P, Santiago, Chile, December.

Uthoff, A. and J. Bravo (1999): Transitional fiscal costs and demographic factors in shifting from unfunded to funded pension in Latin America, Financiamiento del desarrollo series, No. 88, LC/L.1264-P, Santiago, Chile, ECLAC. United Nations publication, Sales No. E.99.II.G.38.

Valdés Prieto, S. (2002): Políticas y mercados de pensiones, un texto universitario para América Latina, Santiago, Chile, Pontificia Universidad Católica de Chile.

Van de Ven, W. and R. Van Vliet (1992): How can we prevent cream skimming in a competitive health insurance market? The great challenge for the 90s, in P. Zweifel and H.E. Frech (eds.), Health Economics Worldwide, Amsterdam, Kluwer Academic Publishers.

Velásquez, M. (2003): Seguros de desempleo, objetivos, características y situación en América Latina, Financiamiento del desarrollo series, No. 133, LC/L.1917-P, Santiago, Chile, ECLAC. United Nations publication, Sales No. S.03.II.G.73.

White, J. (1995): Competing Solutions, Washington, D.C., The Brookings Institution.

WHO (World Health Organization) (2000): World Health Report, 2000, Washington, D.C. 